\title{
Franklin Valley sites
}

SIR - Dr S.J. Paterson accuses me and others of lacking "scientific objectivity" (Nature 29 September, p.354, but see also Nature 15 December, p.636) in our involvement in the recent Australian High Court case over construction of the Franklin dam in the south-west Tasmanian World Heritage area. He quotes me as saying that "it is most unlikely that sites providing material of comparable archaeological value" would be found in southwest Tasmania and goes on to claim that such sites have been found.

Part of the Tasmanian legal strategy was to contest any statement that ascribed special cultural or natural value to the area, which is why the Geological Section of the Hydro-Electric Commission (HEC) conducted its own search for archaeological cave sites in May 1983. This twoweek operation cost $\$ 93,600$ in a state which had not spent a third of that amount on prehistoric field research in the previous ten years. Moreover, the responsible Tasmanian government department, the National Parks and Wildlife Service, which has five qualified archaeologists on its staff, was ignored, as were the procedures for obtaining permission for archaeological research specified by the Aboriginal Relics Act (1975).

No archaeologists were involved. Dr Paterson says that the Association of Consulting Archaeologists had warned its members not to take part but the plan was to dig out the entire deposits of the caves, a procedure that many archaeologists believed was professionally unethical and indeed contrary to the principles of the ICOMOS charter. In any case, very few academic archaeologists in Australia are members of the consulting group, and no archaeologist that I know of was approached to assess the new claims.

Dr Paterson's claim that his team found in different valleys five caves "with content similar to the Franklin Valley caves" is interesting but cannot be assessed while none of the data are published. I note, however, that of his sites, Site 6 on the Andrew River would have been drowned by Stage 2 of the proposed integrated power scheme and that Site 9, Nelson River cave, had already been published six months before the HEC search began and that the only claim for a possible stone artefact was of a single broken cobble $(\mathrm{K}$. Kiernan, A ust. Archaeol. 15, 85-91; 1982).

In the Franklin Valley itself, there is not only Site F34 Kutikina cave with its rich interleaved hearths containing thousands of stone tools, burnt animal bones, bone points and ochre from between $15 \mathrm{kyr}$ and $20 \mathrm{kyr}$ ago (Kiernan et al. Nature 301, 2832; 1983, Ranson et al. Aust. nat. Hist. 21, $83-87 ; 1983$ ) but also one open site and 12 cave sites containing stone tools. One of these caves, F66, Deena Reena, is the largest ever found in the Gordon-Franklin karst, and contains in an erosion gully a geomorphic and archaeological sequence which closely parallels that of Kutikina (Fraser) (Jones et al. Aust. Archaeol. 16, 57-70; 1983, Blain et al. Aust. Archaeol. 16, $71-83$; 1983). A radiometric programme has not yet been completed, but available assays indicate that this cave, together with one other (F82-6) and the open site (FFS-82) have archaeological deposits dating to the height of the last ice age. By contrast, intensive search by our team on two expeditions into the limestone cliffs of the Gordon valley failed to duplicate this richness, with only one small cave containing a few flakelets in over a cubic metre of excavated deposit and one open site dated to approximately 300 years ago being found.

Dr Paterson also states that there are more than 1,000 known caves in the various limestone regions and in the "coastal and midland sandstone formations" of Tasmania. While only some of these have been inspected by archaeologists, I and many colleagues have over the past 20 years carried out systematic searches of several of these areas. With one exception, dated to $10 \mathrm{kyr}$ and published this year $(\mathrm{H}$. Lourandos Aust. Archaeol. 16, 39-47; 1983), no sandstone cave or rock shelter so far investigated has given any evidence of occupation older than $6 \mathrm{kyr}$. No occupation remains have been found in the extensive limestone caves of northern Tasmania at Mole Creek, nor in the north west Montague. Cave sites on the coast have, with one exception, deposits exclusively restricted to Holocene times.

Before the Franklin finds, the only other proven Pleistocene archaeological sites in Tasmania were Beginner's Luck cave in the Florentine Valley, where some 20 stone tools were found in a geologically reworked deposit dated to approximately 20,000 , and Cave Bay cave on Hunter Island where a few stone and bone tools were found in a deposit dated to between 18 and $23 \mathrm{kyr}$. There was an almost complete hiatus until early Holocene sea-shore occupation times (see S. Bowdler Adv. World Archaeol. 1, 39; 1983). The Franklin evidence was to transform this situation.

Yet the original multidisciplinary environmental impact study commissioned by the Hydro-Electric Commission concluded baldly not only that "nothing of archaeological significance has yet been found in any of the caves" but also that "there are no known archaeological sites in the project area". This so concerned the Australian Archaeological Association that in May 1980 it urged on the Premier of Tasmania that "assessments by professional archaeologists are ... essential". Because of their omission, the archaeological significance of the Franklin Valley was not discovered until the final political decisions about the scheme were being publicly debated. Matters seem now to have improved and environmental impact studies under way in areas of proposed HEC dams on the Henty and Anthony rivers of Western Tasmania include an archaeological component directed by professional consultant archaeologists.

Dr Paterson suggested that archaeologists including myself had entered that "wide gap between truth and verisimilitude when science is subordinated to promoting a cause". It is of interest to note that the defendants in the High Court case, which included the Hydro-Electric Commission of Tasmania, argued that the archaeological sites of the Franklin "are not significant in the sense that they are important or the only example of such sites", and further that the number of archaeological remains "in the Kutikina Cave is neither exceptional nor significant". Now that Dr Paterson claims that the five new caves have the "same" archaeological significance as those on the Franklin River, did he never subscribe to the HEC view, has he changed his mind or does he mean the new sites he has found are also unimportant?

Department of Prehistory, Australian National University, Canberra, ACT 2600, Australia

\section{EMBL's programme}

SIR - I would like to correct the impression (Nature 17 November 1983, p.214) that within the new research activities at the European Molecular Biology Laboratory, 32 people work under my guidance on haematopoietic cell differentiation. The fact is that less than half of the staff in the new Differentiation Programme work in this area (under the guidance of $\mathbf{H}$. Beug and myself, formerly Krebsforschungszentrum, Heidelberg). Members of the other three groups work on functions of $\mathrm{v}-$ onc and c-onc genes in various systems ( $R$. Müller, formerly Salk Institute, San Diego; B. Vennström, formerly Biomedical Centre, Uppsala) and on aspects of mouse embryo development (E. Wagner, formerly Fox Chase Cancer Center, Philadelphia). THOMAS GRAF

Programme Coordinator, European Molecular Biology,

Laboratory, 6900 Heidelberg, FRG

\section{Gripes}

SIR - I would like to add to your list of gripes (Nature 10 November 1983, p.134) the use of such terms as "we are at present on a learning curve" (to describe any monotonic time series with negative regression) by writers who obviously are not.

C. R. B. JOYCE

Beim Lindenbaum 15, 4123 Allschwil, Switzerland 